\title{
The Performance Evaluation on Co-Digestion of Domestic Sewage Sludge and Food Waste for Methane Yield and Kinetics Analysis
}

\author{
Siti Mariam Sulaiman ${ }^{1}$, Roslinda Seswoya $^{1^{*}}$ \\ ${ }^{1}$ Micro Pollutant Research Centre, Faculty of Civil Engineering and Built Environment \\ Universiti Tun Hussein Onn Malaysia, 86400 Parit Raja, Batu Pahat, Johor, MALAYSIA \\ *Corresponding Author
}

DOI: https://doi.org/10.30880/ijie.2021.13.03.004

Received 22 September 2020; Accepted 09 March 2021; Available online 01 June 2021

\begin{abstract}
Sewage sludge and food waste; are organic wastes suitable for the anaerobic digestion. However, the digestion of sewage sludge and food waste as solely substrate is having a drawback in term of methane yield. Therefore, many researchers combined these two wastes as a co-substrate and used in co-digestion. This study focused to evaluate the anaerobic co-digestion of domestic sewage sludge (in form of primary and secondary sewage sludge) with food waste under mesophilic temperature in a batch assay. Two series of batch biochemical methane potential (BMP) test were conducted using the Automatic Methane Potential Test System (AMPTS II). Each set are labelled with BMP 1(PSS:FW) and BMP 2 (SSS:FW). The BMP tests were monitored automatically until the methane production is insignificant. Using the data observed in the laboratory, the kinetic paremeters were calculated. Also, the First-order and Modified Gompertz modeling were included to predict the anaerobic digestion performance. Finding showed that BMP 1(PSS:FW) have better performance with respect to the higher ultimate methane yield and methane production rate as compared to BMP 2 (SSS:FW). Besides, the kinetic parameters from laboratory work and modeling were slightly different. In which the kinetic paremetes from modelling is lesser. However, both modelling are well fitted to the experimental data with high correlation coefficient, $\mathrm{R}^{2}$ ranged from 0.993 to 0.997 .
\end{abstract}

Keywords: Domestic sewage sludge, mesophilic, batch, yield

\section{Introduction}

The implementation of sewage sludge treatment has been a challenge for most of countries due to the lack of expertise and fund. Sewage dumping in landfills is the no longer practice in other countries [1]. In European Region, there is a ban on sewage sludge deposit in landfill starting from 2005 [2] Fijalkowski et al. [3] stated that only 39\% of sewage sludge was used in agriculture in the European region. Besides, high-income countries such as the United States of America, Germany, and Canada treated sewage sludge by adapting the anaerobic digestion treatment.

Anaerobic digestion for sewage sludge has a long history. This treatment purposely aimed to get rid and focused on recycling sewage sludge. Afterward, the focus was slowly changed as methane gas of this treatment could be used to generate electricity [4]. Practically, anaerobic digestion of sewage sludge comprised of a mixture of primary and secondary sewage sludge. In addition, anaerobic digestion also actively developed for food waste management sectors [5]. Unfortunately, anaerobic digestion of food waste was inefficient when it is used as a sole substrate [6]. Therefore, co-digestion was used as an alternative. Co-digestion also enhanced the productivity of renewable energy, the possibility of nutrient recycling and reduction of wastes [7]. Recently, co-digestion realized to be more stable when a 
variety of substrates were applied. The most common situation is when many main basic substrates such as sewage sludge are mixed and digested together with a minor amount of as single; a variety of additional substrates [7] It should be realized the potential of food waste to be used as feedstock as it is highly rich in organic matter and nutrients [8]. Easily biodegradable organic is preferable for anaerobic digestion due to the characteristics that easy to degrade in hydrolysis process [9]

Focusing on the co-digestion of sewage sludge and food waste, several laboratory scales for the study of codigestion of sewage sludge and food waste has been conducted [9]-[11]. Almost all these studies show improvement. For instance, Prabhu and Mutnuri [12], found significant improvement of methane yield of $471.1 \mathrm{~mL} \mathrm{CH}_{4} / \mathrm{g} \mathrm{VS}$ with the supplementary of food waste as compared to $385.9 \mathrm{~mL} \mathrm{CH}_{4} / \mathrm{g}$ VS from digestion of sewage sludge alone. Not only limited in laboratory scale, co-digestion of sewage sludge, and food waste also applied at full-scale East Bay Municipal Utility District WWTP is the first plant in the US to implement co-digestion of sewage sludge and food waste. Other than that, the Rovereto plant and Treviso plant in Italy also implemented the co-digestion of sewage sludge and food waste [13]. However, less study of co-digestion of sewage sludge and food waste was reported.

Methane is estimated through the biochemical methane potential test (BMP). BMP is a reliable and well-known test to evaluate the ultimate methane potential per mass of the substrate. According to Valero et al. [14], by adapting the BMP test, the matter removal (in terms of total solid(TS), volatile solid (VS) or chemical oxygen demand (COD)) and the kinetics studies of organic substrate in the anaerobic digestion process could be observed. Simple and practical tools to evaluate the performance of anaerobic digestion for organic waste is a batch reactor. A biochemical methane potential (BMP) batch anaerobic digestion was suitable for determining the degradation of the kinetics and the formation of methane gas [10].

Therefore, this study was aimed to assess the anaerobic co-digestion of primary and secondary sewage sludge with food waste under mesophilic temperature. A series of batch biochemical methane potential (BMP) tests were conducted using the Automatic Methane Potential Test System (AMPTS II). The First order and Modified Gompertz modeling equation were included to predict the anaerobic digestion performance.

\section{Material and Methods}

\subsection{Substrate and Inoculum}

This study used two types of substrates labeled as PSS: FW and SSS: FW, which is a mixture of primary sewage sludge with food waste and secondary sewage sludge with food waste at 4:1 ratio on wet mass [15]. Both types of sewage sludge were sampled from the Universiti Tun Hussein Onn Malaysia( UTHM) sewage treatment plant. On the other hand, food waste (FW) was tested from the campus cafeteria in UTHM too. A major fraction of FW included rice, vegetables, and meats. The samples were screened for non-biodegradable items such as plastics bags and cutlery before blended around two or three minutes using a household blender into a thick consistency with the addition of tap water [16].

The inoculum was taken from the existing full-scale anaerobic digester treating palm oil mill effluent (POME). The inoculum consists of active anaerobic bacteria. The sewage samples, blended food waste, and anaerobically digested sludge were kept in a plastic container stored at $4^{0} \mathrm{C}$ until used in the anaerobic digestion assay [17].

\subsection{Biochemical Methane Potential (BMP) Test}

Two (2) sets of batch BMP test labeled as BMP 1(PSS:FW) and BMP 2(SSS:FW) were performed through Automatic Methane Potential Test System II (AMPTS II) precedence from a recent study by Seswoya et al. [18] using $500 \mathrm{ml}$ Duran bottles as reactors. With the total working volume of $400 \mathrm{ml}$, inoculum, and substrate were filled up according to inoculum to substrate (I/S) ratio of 2:1 on VS basis [14]. The mass of inoculum and substrate added into the reactor was tabulated in Table 1 determined using VS in (\%) as according to Stromberg et al. [19].

Table 1 - Mass of inoculum and substrate filled into the reactors

\begin{tabular}{ccccc}
\hline BMP & Reactor & Mass of inoculum $(\mathbf{g})$ & Mass of Substrate $(\mathbf{g})$ & $\mathbf{p H}$ \\
\hline \multirow{2}{*}{ BMP 1(PSS:FW) } & Blank & 215.7 & - & 7.3 \\
& Substrate & 215.7 & 45.0 & 7.2 \\
\multirow{2}{*}{ BMP 2(SSS:FW) } & Blank & 346.9 & - & 7.1 \\
& Substrate & 346.9 & 53.1 & 7.2 \\
\hline
\end{tabular}

The BMP test was conducted in triplicate sample reactors and duplicated in a blank reactor contained inoculum solely. The substrate and inoculum were shaken to homogenize the solids concentration before pouring into reactors [20]. Besides, to avoid the early reaction that may interrupt the results, the reactors were prepared one after another, and the initial $\mathrm{pH}$ was recorded. The initial $\mathrm{pH}$ ranged from 7.1 to 7.3 are suitable for the anaerobic process. Then, the 
reactors were purged with pure nitrogen $\left(\mathrm{N}_{2}\right)$ gas for two minutes before placed in the unit A of AMPTS II (Fig. 1) at mesophilic temperature $\left(37^{\circ} \mathrm{C}\right)$ [21]. The reactors were mixed automatically at $100 \mathrm{rpm}$ [8].

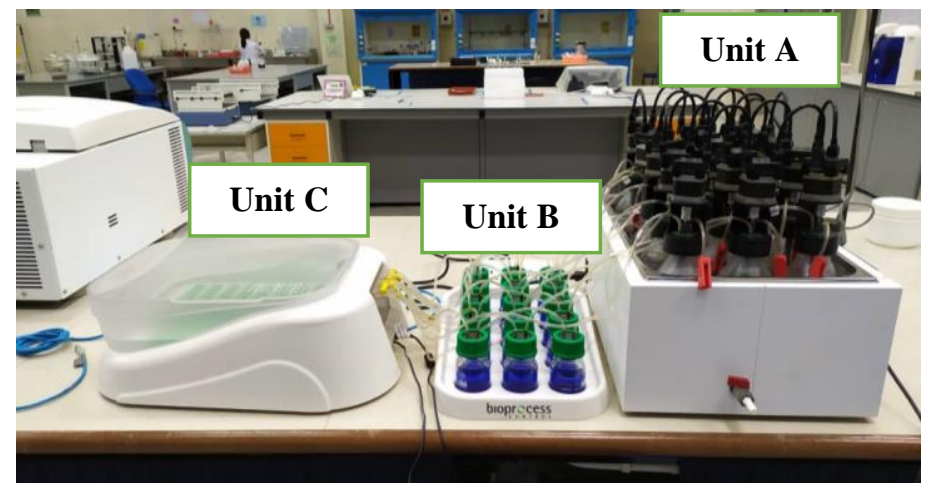

Fig. 1 - Automatic Methane Potential Test System (AMPTS II)

\subsection{Analytical Method}

The analytical method describes the procedure for characterization. Characterization of the substrate is an important parameter reflecting the potential of methane production from the BMP test [22]. The analytical methods used for this study were presented in Table 2. Solid (TS and VS) also applied for BMP setup, and alkalinity was measured to confirm the stability of the anaerobic process. A calibrated $\mathrm{pH}$ meter was used for $\mathrm{pH}$ determination. The soluble form each for substrate and inoculum was prepared by centrifuging the sample and followed by filtration through a $0.45 \mu \mathrm{m}$ cellulose acetate filter [8].

Table 2 - Analytical method

\begin{tabular}{ccc}
\hline Parameter & Analytical Method & Reference \\
\hline $\mathrm{COD}(\mathrm{g} / \mathrm{L})$ & HACH method 8000 & {$[23]$} \\
$\mathrm{TS}(\mathrm{g} / \mathrm{L})$ & APHA: Method 2540B & {$[23]$} \\
$\mathrm{VS}(\mathrm{g} / \mathrm{L})$ & APHA: Method 2540E & {$[24]$} \\
Protein $(\mathrm{g} / \mathrm{L})$ & Lowry Method & {$[25]$} \\
Carbohydrate $(\mathrm{g} / \mathrm{L})$ & Dubois Method & {$[9]$} \\
Alkalinity $\left(\mathrm{gCaCO}_{3} / \mathrm{L}\right)$ & APHA: Method 2320B & {$[9]$} \\
\hline
\end{tabular}

\subsection{Kinetics Analysis}

Two (2) kinetics modeling was used in this study to estimate the performance of the BMP test. The first-order kinetics modeling was applied as it is the simplest model yet can predict the ultimate methane yield and the methane production rate. Since the lag phase also crucial parameter to be observed, modified Gompertz modeling was applied. With aid from Excel Solver, Microsoft Excel kinetics parameters such as ultimate methane yield, maximum methane production rate, and lag phase were estimated from the graph that fits the experimental data set [26].

$$
\begin{gathered}
M=M_{0} \times\left[1-e^{-k t}\right] \\
M=M_{0} \times \exp \left[-\exp \left(\frac{R_{m} \times e}{M_{0}}\right)(1-t)+1\right]
\end{gathered}
$$

where $M$ represents the specific methane yield (mL/g VS) at a digestion time, $M_{0}$ is the methane potential $(\mathrm{mL} / \mathrm{g} \mathrm{VS})$, $R m$ and $k$ stands for the methane production rate (mL/g VS day), e is the Euler's constant (2.7183) and $\lambda$ refer to the lag phase (days).

\section{Results and Discussion}

\subsection{Characteristics of Inoculum}

The inoculum used in this study was taken from a full-scale anaerobic digester. It is common to use the anaerobically digested sludge from full-scale anaerobic digester for the BMP test [27] Table 3 shows the characteristics of the inoculum used in the BMP test. The inoculum was slightly alkaline, with a $\mathrm{pH}$ value of more than 7.0. The 
inoculum contained complex organic, including protein and carbohydrate. As expected, the total protein and carbohydrate were different from the two samples. The protein concentration was always higher than carbohydrates as observed by Cabbai et al. [9] and Zhen et al. [28]. Both samples show the VS / TS of 0.45 and 0.43 for the first and second sampling, respectively. Liu et al [25], reported that inoculum taken from the anaerobic digester (operated at mesophilic temperature) was having a VS/TS ratio of 0.48 . The inoculum having VSS/TSS ratio more than 0.5 was found resuted in higher methane yield due to the remaining organic in the iniculum itself. The use of inoculum with higher methane yield is not appropriate because in the BMP assay, the methane yied from the targeted substrate is subtracted from the methane production obtained in the blank assays (only inoculum) [27].

Table 3 - Inoculum characteristics $(\mathrm{N}=3)$

\begin{tabular}{ccc}
\hline Parameter & Used for BMP1 (PSS:FW) & Used for BMP2 (SSS:FW) \\
\hline Total solids (TS) (g/L) & $19.89 \pm 0.51$ & $16.22 \pm 0.38$ \\
Volatile solids (VS) (g/L) & $8.89 \pm 0.19$ & $7.00 \pm 0.33$ \\
COD total (g/L) & $20.34 \pm 0.25$ & $17.78 \pm 0.19$ \\
COD soluble (g/L) & $6.75 \pm 0.12$ & $5.64 \pm 0.17$ \\
Protein total (g/L) & $4.89 \pm 0.03$ & $4.10 \pm 0.05$ \\
Protein soluble (g/L) & $1.54 \pm 0.02$ & $1.32 \pm 0.01$ \\
Carbohydrate total (g/L) & $1.31 \pm 0.05$ & $1.27 \pm 0.01$ \\
Carbohydrate soluble (g/L) & $0.22 \pm 0.04$ & $0.19 \pm 0.03$ \\
\hline
\end{tabular}

\subsection{Characteristics of Substrates}

The characteristics measurement was carried out as soon as the sample arrived and completed within seven days to minimize errors from the effects of biodegradation due to microbial action. The characteristics are crucial as it reflects the potential in producing methane gas. A small difference of organic matter was observed from the PSS:FW and SSS:FW indicates by 0.94 and 0.93 VS/TS ratio, respectively. Besides, according to Seswoya et al. [21], VS/TS ratio greater than 0.50 represents high organic content in the substrate, thus easy to biodegradable. The protein is much higher as compared to carbohydrate observed consistently in both substrates. The soluble COD, proteins, and carbohydrates concentration for PSS:FW were relatively higher than what was seen from SSS:FW. As expected, the soluble form of COD, proteins, and carbohydrates than particulate form was lower. The finding is similar to what was observed by Cabbai et al. [9], and Zhen et al. [29].

Table 4 - Substrate characteristics $(\mathrm{N}=3)$

\begin{tabular}{ccc}
\hline Parameter & PSS:FW & SSS:FW \\
\hline Total solids (TS) $(\mathrm{g} / \mathrm{L})$ & $79.64 \pm 1.37$ & $78.56 \pm 3.20$ \\
Volatile solids $(\mathrm{VS})(\mathrm{g} / \mathrm{L})$ & $74.53 \pm 4.85$ & $73.20 \pm 1.17$ \\
COD total $(\mathrm{g} / \mathrm{L})$ & $72.30 \pm 0.01$ & $70.69 \pm 0.01$ \\
COD soluble $(\mathrm{g} / \mathrm{L})$ & $13.62 \pm 0.04$ & $13.92 \pm 0.02$ \\
Protein total $(\mathrm{g} / \mathrm{L})$ & $3.73 \pm 0.25$ & $3.32 \pm 0.30$ \\
Protein soluble $(\mathrm{g} / \mathrm{L})$ & $0.25 \pm 0.00$ & $0.23 \pm 0.01$ \\
Carbohydrate total $(\mathrm{g} / \mathrm{L})$ & $6.11 \pm 0.15$ & $6.00 \pm 0.10$ \\
Carbohydrate soluble $(\mathrm{g} / \mathrm{L})$ & $0.72 \pm 0.00$ & $0.68 \pm 0.00$ \\
\hline
\end{tabular}

\subsection{Stability of Anaerobic Process for BMP Test}

The stability of the anaerobic process in the BMP test is essential as it shows the efficiency of the test. For batch reactors, the stability is determined by determining the $\mathrm{pH}$ and alkalinity. The $\mathrm{pH}$ was measured before and after digestion. Any value of $\mathrm{pH}$ is acceptable as long as the $\mathrm{pH}$ is in the range of acceptable $\mathrm{pH}$ for the anaerobic process. In addition, alkalinity also conducted to verify the stability of the BMP process in the form of intermediate alkalinity (IA) and partial alkalinity(PA) and the ratio of IA/PA. The final $\mathrm{pH}$ for BMP 1(PSS:FW) was recorded varies from 7.1 to 7.5 .

On the other hand, BMP 2(SSS:FW) final $\mathrm{pH}$ varies from 7.3 to 7.6. It seems that the $\mathrm{pH}$ remained in the $\mathrm{pH}$ suitable for the anaerobic process, which is from 5.5 to 8.5 [30]. Both BMP tests were in stable condition indicates by IA/PA less than 0.4; which the alkalinity varies from 0.04 to 0.15 and 0.14 to 0.15 for BMP 1(PSS:FW) and BMP 
2(SSS:FW) respectively, indicating that the anaerobic process was stable throughout the study period. Cabbai, et al., [9] stated that IA/PA lesser than 0.4 is showing the steady anaerobic process.

\subsection{Methane Accumulation}

Net methane accumulation is the difference between methane production from the sample reactor and the blank reactor [21]. The net methane accumulation for BMP 1(PSS:FW) and BMP 2(SSS:FW) were presented in Table 5. The net methane accumulation from the BMP 1(PSS:FW) was higher than the net methane observed from the BMP 2(SSS:FW). These findings are coincidence with previous studies by Dinh et al. [31] and Xie et al. [32]. However, the digestion of co-substrate BMP 1(PSS: FW) resulted in higher net accumulated methane, about 530.4ml as compared to BMP 2(SSS:FW), because PSS:FW having a slightly higher organic as indicated by higher VS/TS and COD.

Table 5 - Methane accumulation for BMP assay

\begin{tabular}{lcccc}
\hline \multicolumn{1}{c}{ BMP } & \multicolumn{2}{c}{ BMP 1(PSS:FW) } & \multicolumn{2}{c}{ BMP 2(SSS:FW) } \\
\hline Volume (mL) & Blank Reactor & Sample Reactor & Blank Reactor & Sample Reactor \\
\hline Average accumulated methane & 53.9 & 584.3 & 58.9 & 487.0 \\
Net accumulated methane & \multicolumn{2}{c}{530.4} & 428.1 \\
\hline
\end{tabular}

\subsection{Ultimate Methane Yield}

The digestion period for the BMP tests was 15 days. As presented in Fig. 2, both digestion shows rapidly start, but the methane yield at a different time with one day difference. There is no lag phase observed for each BMP test. Starting from the $12^{\text {th }}$ day of BMP assay, it was found that methane production has come to a stop. Due to the higher organic content in BMP 1(PSS:FW), the ultimate methane yield was also observed higher than BMP 2(SSS:FW). The ultimate methane yield for the BMP 1(PSS:FW) was $1233.57 \mathrm{~mL} \mathrm{CH}_{4} / \mathrm{g}$ VS starting from the $13^{\text {th }}$ day. On the other hand, the ultimate methane yield for BMP 2(SSS:FW) was observed starting from the $12^{\text {th }}$ day. The ultimate methane yield for BMP 2(SSS:FW) was $995.5 \mathrm{~mL} \mathrm{CH}_{4} / \mathrm{g}$ VS, lesser about $237.99 \mathrm{~mL} \mathrm{CH}_{4} / \mathrm{g}$ VS than the ultimate methane yield for BMP 1(PSS:FW), resulted in an indifference about $19.30 \%$.

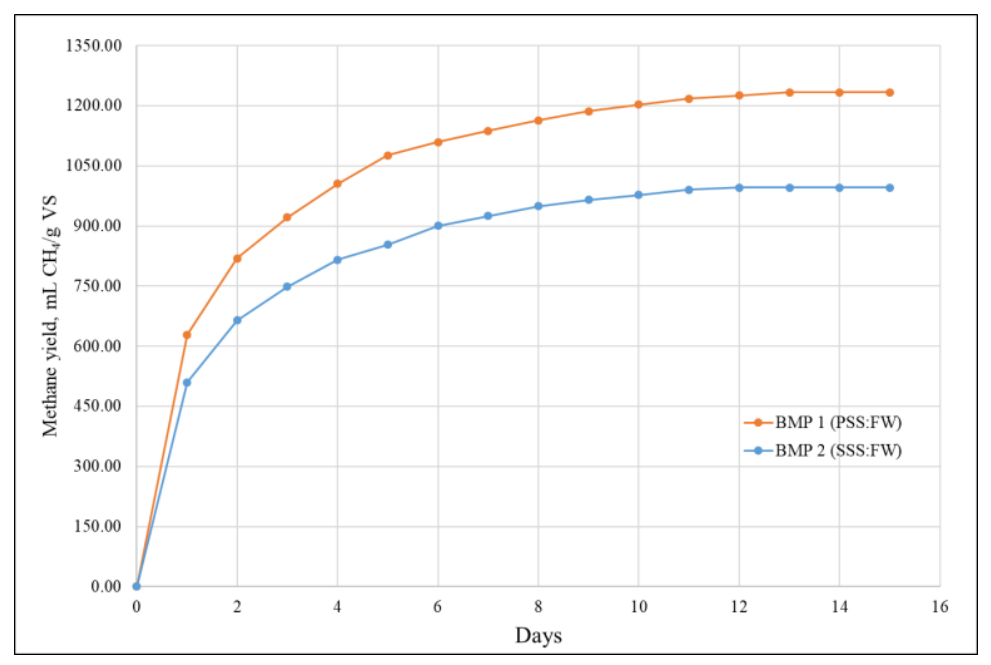

Fig. 2 - The methane yield curve

The ultimate methane yield for the BMP 1(PSS:FW) is higher than BMP 2(SSS:FW). As observed, the PSS:FW contained slightly higher organic content compared to SSS: FW. Pan et al. [29] and Xie et al. [32] also have a similar observation and pointed out that the variations in TS, VS of the substrate significantly influenced the methane production. Li et al. [33] also supported this difference, that stated the methane yield and methane production could be different due to the facts of different substrate characteristics and varied source of samples. Prabhu \& Mathuri [12] stated that lower methane production probably due to lower inoculum to substrate ratio.

\subsection{Methane Production Rate}


In general, the co-digestion of BMP 1(PSS:FW) and BMP 2(SSS:FW) shows quick initial methane production demonstrated by steeper slope from the curve (Fig. 1). Both BMP shows a fast methane production rate indicating no acclimation period occurs. Table 6 summarized the maximum methane production rate. The characteristics of the substrate mostly influence the methane production rate. BMP 1(PSS: FW) showed a higher methane production rate influenced by the high value of carbohydrate and soluble organic as compared to the co-substrate of BMP 2(SSS: FW). These findings corresponded well with results revealed by Li et al. [33], which observed that the anaerobic digestion with high carbohydrate content produced fast methane production rate. Wang et al. [34] and Elsayed et al. [35], stating that small particle size of the substrate and soluble concentration also ascent the methane production rate as it is ready to degrade. A high amount of soluble concentration accelerated the methane production rate in anaerobic digestion since it is readily degradable. Other studies of co-digestion between primary sewage sludge and food waste conducted by Pan et al. [29] also showed similar trends.

Table 6 - Methane yield for BMP assay

\begin{tabular}{ccc}
\hline BMP & BMP 1(PSS:FW) & BMP 2(SSS:FW) \\
\hline Methane production rate $(\mathrm{mL} \mathrm{CH4/g} \mathrm{VS} \mathrm{d)}$ & 628.18 & 510.16 \\
\hline
\end{tabular}

\subsection{Methane Production Kinetic Modeling}

Two (2) kinetic modeling adapted to fit and determine the methane production in the batch BMP test in this study. The first-order kinetics describes only two kinetic parameters, which are the ultimate methane yield (Mo) and methane production rate (k). Hence, Modified Gompertz (Eq. (2)), the lag phase could be determined too.

Table 7 presented the experimental data with the kinetic analysis using First-order kinetics. First-order analyzed similar value for both the BMP test. Parra-orobio et al. [36] stated that the methane production rate, $\mathrm{k}$ in the range of $0.025-0.2 \mathrm{~d}^{-1}$ is possible if the substrate is rich in carbohydrate. This study observed the higher $\mathrm{k}$, ranged 0.4 to $0.7 \mathrm{l} / \mathrm{d}$. Iqbal Syaichurrozi \& Sumardiono [37] stated that a high value of $\mathrm{k}$ means that the faster rate of methane is produced and the high value of $\mathrm{k}$ may influence the methane production yield. In contrast, the ultimate methane yield observed from modeling is fluctuated in such a way the improved ultimate methane yield was observed for BMP 2 (SSS: FW).

Adapting first-order modeling shows a lower parameter than observed through experimental data. Algapani et al. [38] found that lower methane yield and methane production rate than experimental data. The results of the correlation coefficient, $\mathrm{R}^{2}$ ranged from 0.997 to 0.999 was observed by this study, relatively higher than average. On average, the $\mathrm{R}^{2}$ for co-digestion of sewage sludge and food waste studies were shown to have values ranged from 0.890 to 0.960 [8], [39].

Table 7 - Kinetic parameters from laboratory and first order modelling

\begin{tabular}{ccccc}
\hline BMP test & \multicolumn{2}{c}{ BMP 1 (PSS:FW) } & \multicolumn{2}{c}{ BMP 2 (SSS:FW) } \\
\hline Kinetic Parameter & Experimental & First-order & Experimental & First-order \\
\hline $\begin{array}{c}\text { Ultimate methane yield, } \mathrm{M}_{\mathrm{o}}\left(\mathrm{mLCH}_{4} / \mathrm{gVS}\right) \\
\begin{array}{c}\text { Methane production rate, } \mathrm{k} \\
(\mathrm{mL} \mathrm{CH} / \mathrm{gVS} / \text { day })\end{array}\end{array} \mathrm{R}^{2}$ & 0.40 & 0.66 & 0.40 & 0.66 \\
$\mathrm{R}^{2}$ & \multicolumn{2}{c}{0.997} & \multicolumn{2}{c}{0.997} \\
\hline
\end{tabular}

Table 8 - Kinetic parameters from laboratory and Modefied Gompertz modelling

\begin{tabular}{ccccc}
\hline BMP test & \multicolumn{2}{c}{ BMP 1 (PSS:FW) } & \multicolumn{2}{c}{ BMP 2 (SSS:FW) } \\
\hline Kinetic Parameter & Experimental & $\begin{array}{c}\text { Modified } \\
\text { Gompertz }\end{array}$ & Experimental & $\begin{array}{c}\text { Modified } \\
\text { Gompertz }\end{array}$ \\
\hline $\begin{array}{c}\text { Ultimate methane yield, } \mathrm{M}_{\mathrm{o}} \\
\text { (mLCH} / \mathrm{gVS})\end{array}$ & 1233.57 & 1158.43 & 995.58 & 938.41 \\
$\begin{array}{c}\text { Methane production rate, } \mathrm{k} \\
(\mathrm{mL} \mathrm{CH} / \mathrm{gVS} / \text { day) } \\
\text { Lag phase (day) }\end{array}$ & 628.18 & 576.86 & 510.16 & 468.73 \\
$\mathrm{R}^{2}$ & 0.04 & 0.00 & 0.04 & 0.00 \\
\hline
\end{tabular}


Based on the modeling analysis, the lag phase was not available at all. In contrast, the experimental data showed that the co-digestion resulted in the lag phase of 0.04 days. The finding is found to be similar to what was observed by Algapani et al. [38].

Many studies have adapting Modified Gompertz were mostly found lower value for the kinetic parameters as compared to the experimental work [40]. Also, lower $\mathrm{R}^{2}$ ranged from 0.967 to 0.994 for the co-digestion study was observed. Unlike the previous research, this study found higher $\mathrm{R}^{2}$ ranged from 0.993 to 0.997 . These values corroborate the ideas of Zhen et al. [41], who suggested that $\mathrm{R}^{2}$ near to 1 shows satisfactory agreement between the actual and predicted values.

\section{Conclusion}

Two co-digestion sets of sewage sludge with food waste were done in this study, and each was labeled as BMP1 (PSS:FW) and BMP2 (SSS: FW). For each co-digestion test, the different inoculum was used. The inoculum was found to have low organic content, as indicated by the VS/TS ratio lesser than 0.5. Meanwhile, the co-substrates are having higher organic substances, as indicated by the VS/TS ratio of more than 0.90. Besides, the PSS:FW was slightly improved bioavailability subsequently resulted in higher methane accumulation.

BMP 1(PSS:FW) has resulted in a high value of ultimate methane yield of $1233.57 \mathrm{~mL} \mathrm{CH}_{4} / \mathrm{g}$ VS; increased by $19.30 \%$ difference than BMP 2(SSS:FW). The co-digestion of PSS:FW was also found the improved methane production rate. No lag phase was observed for each co-digestion study, indicated that a mixture of sewage sludge with food waste at a 4:1 ratio is suitable for anaerobic co-digestion. Besides, the methane kinetics parameters calculated from laboratory work was slightly different from the observation from modeling analysis. However, both models are well fitted to the experimental data with a high correlation coefficient; $\mathrm{R}^{2}$ ranged from 0.993 to 0.997 .

\section{Acknowledgment}

This project has been funded with support from Universiti Tun Hussein Onn Malaysia through GPPS-Vot U945 and TIER 1 - Vot U844. The authors also gratefully acknowledge the support and assistance of Cenergi SEA Sdn. Bhd.

\section{References}

[1] Kaur G., Luo L., Chen G. \& Wong J. W. C. (2019). Integrated food waste and sewage treatment - a better approach than conventional food waste-sludge co-digestion for higher energy recovery via anaerobic digestion. Bioresource Technology, 289, 121698

[2] Cusido J. A., Cremades L. V. \& Gonza' lez M. (2003). Gaseous emissions from ceramics manufactured with urban sewage sludge during firing processes. Waste Management, 23, 273-280

[3] Fijalkowski K., Rorat A., Grobelak A. \& Kacprzak M. J. (2017).The presence of contaminations in sewage sludge-The current situation. J. Environ. Manage, 203, 1126-1136

[4] Sembera C., Macintosh C., Astals S. \& Koch K. (2019). Benefits and drawbacks of food and dairy waste codigestion at a high organic loading rate : A Moosburg WWTP case study. Waste Management, 95, 217-226

[5] Jabeen M., Zeshan,. Yousaf S., Haider M. R. \& Malik R. N. (2015). High-solids anaerobic co-digestion of food waste and rice husk at different organic loading rates. International Biodeterioration and Biodegradation, $102,149-153$

[6] Liao X., Zhu S., Zhong D., Zhu J. \& Liao L. (2014). Anaerobic co-digestion of food waste and landfill leachate in single-phase batch reactors. Waste Management, 34(7), 2278-2284

[7] Maragkaki A. E., Fountoulakis M., Gypakis A., Kyriakou A., Lasaridi K. \& Manios T. (2017). Pilot-scale anaerobic co-digestion of sewage sludge with agro-industrial by-products for increased biogas production of existing digesters at wastewater treatment plants. Waste Management, 59, 362-370

[8] Ma Y., Yin Y. \& Liu Y. (2017). New insights into co-digestion of activated sludge and food waste: Biogas versus biofertilizer. Bioresource Technology, 241, 448-453

[9] Cabbai V., Ballico M., Aneggi E. \& Goi D. (2013). BMP tests of source selected OFMSW to evaluate anaerobic codigestion with sewage sludge. Waste Management, 33(7), 1626-1632

[10] Koch K., Plabst M., Schmidt A., Helmreich B. \& Drewes J. E. ( 2016). Co-digestion of food waste in a municipal wastewater treatment plant: Comparison of batch tests and full-scale experiences. Waste Management, 47, 28-33

[11] Nielfa A., Cano R., Pérez A. \& Fdez-Polanco M. (2015). Co-digestion of municipal sewage sludge and solid waste: Modelling of carbohydrate, lipid and protein content influence. Waste Management Research, 33(3) 241249

[12] Prabhu M. S. \& Mutnuri S. (2016). Anaerobic co-digestion of sewage sludge and food waste. Waste Management Research, 34(4), 307-315

[13] Nghiem L. D., Koch K., Bolzonella D. \& Drewes J. E. (2017). Full scale co-digestion of wastewater sludge and food waste : Bottlenecks and possibilities. Renewable and Sustainable Energy Reviews, 72, 354-362 
[14] Valero D., Montes J. A., Rico J. L. \& Rico C. (2016). Influence of headspace pressure on methane production in Biochemical Methane Potential (BMP) tests. Waste Management, 48, 193-198

[15] Dai X., Duan N., Dong B. \& Dai L. (2013). High-solids anaerobic co-digestion of sewage sludge and food waste in comparison with mono digestions: Stability and performance. Waste Management, 33(2) pp. 308-316

[16] Malakahmad A., Md Zain S. \& Ahmad Basri N. E. (2012). biomethanation of kitchen waste and sewage sludge in anaerobic baffled reactor. Proceeding of IEEE Symposium Humanities, Sciences and Engineering Research, pp. $1513-1516$

[17] Grosser A., Neczaj E., Singh B. R., Almås Å. R., Brattebø H. and Kacprzak M. (2017). Anaerobic digestion of sewage sludge with grease trap sludge and municipal solid waste as co-substrates. Environmental Research, 155, 249-260

[18] Seswoya R., Fahmi M. \& Darnak N. A. (2018). Batch biodegradability study of fresh and aged food waste: Performance and kinetic batch biodegradability study of fresh and aged food waste. Proceeding of International Conference of Architecture and Civil engineering ( ICACE), Kuala Lumpur

[19] Strömberg S., Nistor M. \& Liu J. (2015). Early prediction of biochemical methane potential through statistical and kinetic modelling of initial gas production. Bioresource Technology, 176(11) 233-241

[20] Seswoya R. \& Abdul Karim A. T. (2016). Organics characteristics of sludge from a full-scale anaerobic digester treating domestic mixed sewage sludge. International Symposium on Civil and Environmental Engineering. MATEC, 103, 1-8

[21] Seswoya R., Tarmizi A., Karim A., Darnak N. A., Fahmi M. \& Rahman A. (2018). Methane potential from the digestion of food waste in a batch reactor. International Journal of Engineering and Technology, 7 (3.23), 36-39

[22] Alepu O. E., Wang K., Jin Z., Segun G. A., Li Z. \& Ikhumhen H. O. (2016). Comparison biomethane potential (BMP) test of sewage sludge recovered from different treatment processes. International Journal Waste Resource, 6(3), 3-7

[23] Ergu T. H., Tezel U., Gu E. \& Demirer G. N. (2001). Anaerobic biotransformation and methane generation potential of cheese whey in batch and UASB reactors. Waste Management, 21, 643-650

[24] Park K. Y., Jang H. M., Park M. R., Lee K., Kim D. \& Kim Y. M. (2016). Combination of different substrates to improve anaerobic digestion of sewage sludge in a wastewater treatment plant. International Biodeterioration Biodegradation, 109, 73-77

[25] Liu C., Li H., Zhang Y. \& Liu C. (2016). Improve biogas production from low-organic-content sludge through high-solids anaerobic co-digestion with food waste. Bioresource Technology, 219, 252-260

[26] Demir S., Karadeniz A., Civelek Yoruklu H. \& Manav Demir N. (2017). An MS excel tool for parameter estimation by multivariate nonlinear regression in environmental engineering education. Sigma Journal Engineering Nature, 35 (2), 265-273

[27] Elbeshbishy E., Nakhla G. \& Hafe H. (2012). Biochemical methane potential (BMP) of food waste and primary sludge: Influence of inoculum pre-incubation and inoculum source. Bioresource Technology, 110, 18-25

[28] Zhen G., Lu X., Kobayashi T., Kumar G. \& Xu K. (2016). Anaerobic co-digestion on improving methane production from mixed microalgae (Scenedesmus sp., Chlorella sp.) and food waste: Kinetic modeling and synergistic impact evaluation. Chemical Engineering Journal, 299, 332-341

[29] YangPan, Zhongxiang Z., Guangyin Z., Xueqin L., Péter B., Yu-You L., Youcai Z. \& Rajesh Banu J. (2019). Synergistic effect and biodegradation kinetics of sewage sludge and food waste mesophilic anaerobic co-digestion and the underlying stimulation mechanisms. Fuel, 253, 40-49

[30] Kangle K. M., Kore S. V. \& Kulkarni G. S. (2012). Recent trends in anaerobic codigestion : A review. Universal. Journal Environmental Research and Technology, 2 (4), 210-219

[31] Dinh S. T. H. M. G., Fujiwara P. V. \& Pham Phu T. (2018). Kinetic of biogas production in co-digestion of vegetable waste, horse dung, and sludge by batch reactors. Proceesing of International Conference on Environement and Renewable Energy, IOP, 159, 1-8

[32] Xie S., Wickham R. \& Nghiem L. D. (2017). Synergistic effect from anaerobic co-digestion of sewage sludge and organic wastes. International Biodeterioration and Biodegradation, 116, 191-197

[33] Zhipeng L., Zhen C., Hong Y., Yuanpeng W., Weiang L., Jo-Shu C., Qingbiao L. \& Ning H. (2018). Anaerobic co-digestion of sewage sludge and food waste for hydrogen and VFA production with microbial community analysis. Waste Management, 78, 789-799

[34] Wang N., Zheng T. \& Ma Y. (2019). New insights into the co-locating concept on synergistic co-digestion of sewage sludge and food waste towards energy self-sufficient in future WWTPs. Bioresource Technology Reports, 100351

[35] Elsayed M., Andres Y., Blel W. \& Gad A. (2015). Methane production by anaerobic co-digestion of sewage sludge and wheat straw under mesophilic conditions. International Journal of Scientific and Technology Research, 4(6), 1-6

[36] Parra-Orobio B. A., Donoso-Bravo A., Ruiz-Sánchez J. C., Valencia-Molina K. J. \& Torres-Lozada P. (2018). Effect of inoculum on the anaerobic digestion of food waste accounting for the concentration of trace elements. Waste Management, 71, 342-349 
[37] Iqbal Syaichurrozi B. \& Sumardiono S. (2014). Kinetic model of biogas yield production from vinasse at various initial ph: comparison between modified gompertz model and first order kinetic model. Research Journal of Applied Sciences, Engineering and Technology, 7(13), 2798-2805

[48] Dalal E. A., Jing W., Wei Q., Min S., Andrea G., Simon M. W., Mengmeng J., Xiang P., Fabrizio A. \& Renjie D. (2017). Improving methane production and anaerobic digestion stability of food waste by extracting lipids and mixing it with sewage sludge. Bioresource Technology, 244(6), 996-1005

[39] Parra-Orobio B. A., Torres-Lozada P. \& Marmolejo R. (2017). Anaerobic digestion of municipal biowaste for the production of renewable energy: Effect of particle size. Engineering Brazilian Journal Chemical, 34(02), 481-491

[40] Van D. P., Fujiwara T., Tho B. L., Phu P., Toan S. \& Minh G. H. (2020). A review of anaerobic digestion systems for biodegradable waste: Configurations, operating parameters, and current trends, Environment Engineering Research, 25(1), 1-17

[41] Zhen G., Lu X., Kobayashi T., Li Y. Y., Xu K. \& Zhao Y. (2015). Mesophilic anaerobic co-digestion of waste activated sludge and Egeria densa: Performance assessment and kinetic analysis. Applied Energy, 148, 78-86 